\title{
Autoantibodies against neuronal surface proteins in spontaneous subarachnoid and intracerebral haemorrhage
}

\author{
Harald Hegen ${ }^{1}$, Raimund Helbok ${ }^{1}$, Mario Kofler ${ }^{1}$, Bettina Pfausler ${ }^{1}$, Alois Schiefecker ${ }^{1}$, Erich Schmutzhard \\ and Ronny Beer ${ }^{1,2^{*}}$
}

\begin{abstract}
Background: Brain autoimmunity has been reported in patients with preceding infection of the central nervous system by herpesviridae. It has been hypothesized that neuronal damage releasing antigens might trigger secondary immune response. The objective of the study was to investigate whether brain damage due to spontaneous subarachnoid haemorrhage $(\mathrm{SAH})$ or intracerebral haemorrhage $(\mathrm{ICH})$ induces reactivity against neuronal surface proteins.

Methods: Patients with spontaneous SAH and ICH, who had cerebrospinal fluid (CSF) and serum sampling within 2 weeks after disease onset (baseline) and afterwards at least 10 days later (follow-up), were included. Antibodies against NMDA, GABA-B, AMPA-1/- 2 receptor, LGI1 and CASPR2 were determined by indirect immunofluorescence.

Results: A total of $43 \mathrm{SAH}$ and $11 \mathrm{ICH}$ patients aged $62( \pm 12)$ years (65\% females) had simultaneous CSF/ serum sampling median 5 and 26.5 days after disease onset. At baseline, all CSF samples were collected via ventricular drainage, at followup 20 (37.0\%) patients had CSF collection by lumbar puncture because ventricular drain had been already removed. All CSF and serum samples at baseline and follow-up tested negative for antibodies against NMDA, GABA-B, AMPA-1/- 2 receptor, LGI1 and CASPR2.
\end{abstract}

Conclusions: Immunoreactivity against common neuronal surface proteins was not observed within the early disease course of spontaneous SAH and ICH.

Keywords: Subarachnoid haemorrhage, Intracerebral haemorrhage, Immunoreactivity, Neuronal surface proteins, NMDA receptor, GABA $A_{B}$ receptor, AMPA receptor, LGI-1, CASPR-2

\section{Background}

Spontaneous subarachnoid haemorrhage (SAH) and spontaneous intracerebral haemorrhage (ICH) are both severe neurological disorders that result in brain injury due to several mechanisms including primary mechanical tissue damage caused by the bleeding and secondary effects such as inflammatory processes, oxidative stress responses, brain edema and in case of SAH delayed cerebral ischemia [1,2].

With cell injury and blood brain barrier disruption antigens are released into the intrathecal space and, therefore, abundantly presented to the immune

\footnotetext{
* Correspondence: ronny.beer@i-med.ac.at

${ }^{1}$ Department of Neurology, Medical University of Innsbruck, Innsbruck, Austria

${ }^{2}$ Neurological Intensive Care Unit, Department of Neurology, Medical University of Innsbruck, Anichstrasse 35, A-6020 Innsbruck, Austria
}

system. This may result in breaking tolerance and in the formation of an immune response. Brain autoimmunity has been observed in patients with preceding infections of the central nervous system (CNS) by herpesviridae [3-8]. In these patients, antibodies against $\mathrm{N}$-methyl-D-aspartate (NMDA) receptor and other, so far unknown neuronal surface antigens, appeared between one to several weeks after disease onset [3]. It has been hypothesized that antigens being released through neuronal damage trigger secondary immune reactivity [9].

In the present study, we aimed to investigate whether acute brain damage due to spontaneous SAH or $\mathrm{ICH}$ induces the formation of antibodies against neuronal surface proteins in the early and post-acute phase.

(c) The Author(s). 2018 Open Access This article is distributed under the terms of the Creative Commons Attribution 4.0 International License (http://creativecommons.org/licenses/by/4.0/), which permits unrestricted use, distribution, and 


\section{Methods}

\section{Patients and samples}

Patients with spontaneous $\mathrm{SAH}$ and $\mathrm{ICH}$ admitted within $24 \mathrm{~h}$ of disease onset to the neuro-intensive care unit of Medical University of Innsbruck have been recorded in a computerized database since April 2010 and July 2011, respectively. Diagnoses were confirmed by computed tomography of the head and traumatic causes were excluded. Only patients who had ventricular cerebrospinal fluid (CSF) and serum sampling within 2 weeks after disease onset (baseline) and afterwards at least 10 days later (follow-up), were included into this retrospective analysis. At follow-up, also lumbar CSF analysis was eligible in case of lacking ventricular CSF sampling (Fig. 1). All CSF and serum samples were withdrawn simultaneously and stored at $-20{ }^{\circ} \mathrm{C}$ until analysis.

\section{Immunofluorescence assay}

Antibodies against NMDA, $\gamma$-aminobutyric acid type $B$ $\left(\mathrm{GABA}_{\mathrm{B}}\right), \alpha$-amino-3-hydroxy-5-methyl-4-isoxazolepropionic acid (AMPA)-1, AMPA-2 receptor and against the voltage-gated potassium channel (VGKC)-associated proteins leucine-rich glioma inactivated 1 (LGI1) and contactin-associated protein 2 (CASPR2) were determined in CSF and serum at baseline and follow-up by commercially available cell-based indirect immunofluorescence assays (Cat.No. FA112d-1010-51, FA112l1005-50, FA112k-1005-1 and FA1439-1005-1; Euroimmun, Lübeck, Germany).

Briefly, CSF and serum samples were added to an object plate containing human embryonic kidney cells, which express the respective antigen on their surface. After incubation, detection of patients' autoantibodies was achieved by fluorescein isothiocyanate-conjugated anti-human immunoglobulin $G$ antibodies that were finally visualized by fluorescence microscopy.

\section{Statistical analysis}

We performed statistical analysis using SPSS 23.0 (SPSS Inc., Chicago, IL). Distribution of data was assessed by Kolmogorov-Smirnov test and, accordingly, data were displayed as mean \pm standard deviation (SD) or as median and interquartile range (IQR).

\section{Results}

A total of $43 \mathrm{SAH}$ and $11 \mathrm{ICH}$ patients aged $62( \pm 12)$ years comprising $65 \%$ females had simultaneous CSF and serum sampling at baseline, median 5 (IQR 3-8) days after disease onset, and at follow-up after 26.5 (19-35.5) days. At baseline, all CSF samples were collected via ventricular drainage. At follow-up, 15 (34.9\%) SAH and 5 (45.5\%) $\mathrm{ICH}$ patients had CSF collection by lumbar puncture because ventricular drain had been already removed. Demographic and main sample characteristics for each disease group are displayed in Table 1.

\section{Negative antibodies against neuronal surface proteins}

All CSF and serum samples at baseline and follow-up were tested negative for antibodies against NMDA, $\mathrm{GABA}_{\mathrm{B}}$, AMPA-1, AMPA-2 receptor and against the VGKC-associated proteins LGI1 and CASPR2.

\section{Discussion}

According to recent reports on patients with CNS infection by herpesviridae who developed secondary brain autoimmunity as shown by the detection of anti-NMDA receptor antibodies and other so far unknown neuronal surface antibodies within weeks after disease onset [3-8], one might hypothesize that neuronal damage in other CNS disorders might also result in the formation of a secondary immune response. In the present study, we screened for antibodies against NMDA, GABA ${ }_{B}$, AMPA-1, AMPA-2 receptors and against the VGKC-associated proteins LGI1
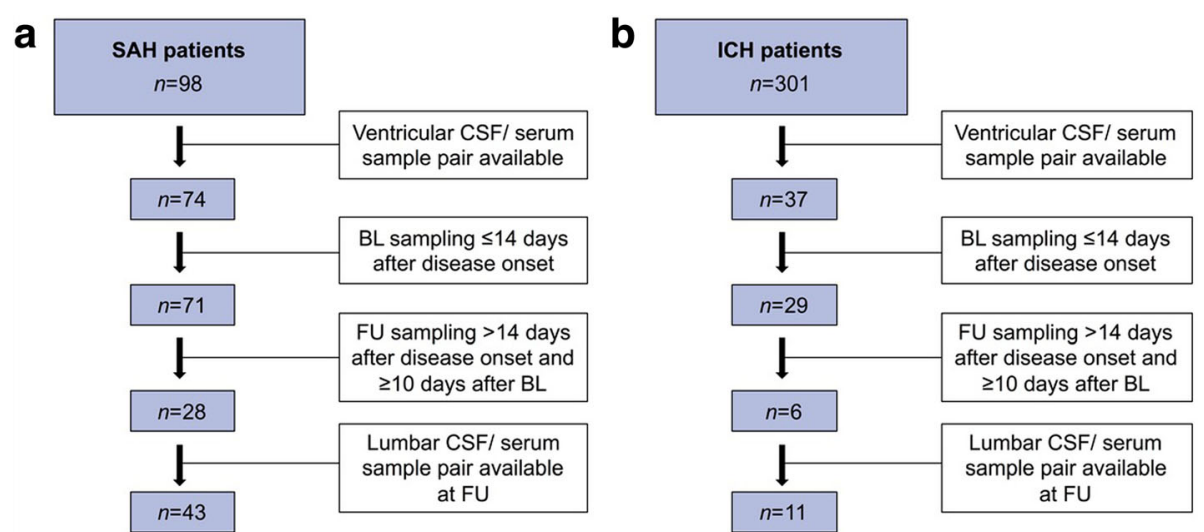

Fig. 1 Sample Flow Chart. a Subarachnoid haemorrhage patient cohort; $\mathbf{b}$ Intracerebral haemorrhage patient cohort. A total of 43 SAH and 11 ICH patients had simultaneous CSF and serum sampling at baseline and at follow-up 
Table 1 Demographic data and cerebrospinal fluid characteristics at baseline and follow-up

\begin{tabular}{|c|c|c|}
\hline & $\mathrm{SAH}$ & $\mathrm{ICH}$ \\
\hline $\mathrm{n}$ & 43 & 11 \\
\hline Age, years; mean \pm SD (range) & $60.7 \pm 12.2(28-86)$ & $67.6 \pm 9.3(55-85)$ \\
\hline Sex, female; n (\%) & $29(67.4)$ & $6(54.5)$ \\
\hline \multicolumn{3}{|l|}{ Hunt \& Hess, n (\%) } \\
\hline Grad I-II & $6(14.0)$ & \\
\hline Grad III & $12(27.9)$ & \\
\hline Grad IV-V & $25(58.1)$ & \\
\hline Time between disease onset and BL sampling, days & $5(3-8)$ & $6(4-9)$ \\
\hline Time between disease onset and FU sampling, days & $27(19-39)$ & $26(19-33)$ \\
\hline \multicolumn{3}{|l|}{ Baseline CSF findings } \\
\hline $\mathrm{RBC}, / \mu \mathrm{l}$ & $32,000(10667-96,000)$ & $30,000(3093-130,000)$ \\
\hline $\mathrm{WBC}, / \mu \mathrm{l}$ & $91(28-371)$ & $73(35-363)$ \\
\hline Total protein, mg/l & $1910(880-2870)$ & $2520(1040-4280)$ \\
\hline \multicolumn{3}{|l|}{ FU CSF findings } \\
\hline $\mathrm{RBC}$ count, $/ \mu \mathrm{l}$ & $106(13-419)$ & $72(3-3072)$ \\
\hline WBC count, $/ \mu \mathrm{l}$ & $9(2-18)$ & $18(10-36)$ \\
\hline Total protein, mg/l & $410(320-690)$ & $840(445-1625)$ \\
\hline
\end{tabular}

Data are given as median (interquartile range) unless otherwise specified

$B L$ baseline, CSF cerebrospinal fluid, FU follow-up, ICH intracerebral haemorrhage, $R B C$ red blood cell, SAH subarachnoid haemorrhage, WBC white blood cell

and CASPR2 in the CSF and serum of patients with spontaneous SAH and $\mathrm{ICH}$. Within a median time period of approximately 4 weeks after disease onset, we did not obtain any positive result.

There might be several reasons for the absence of a secondary immune response in our cohort of SAH and $\mathrm{ICH}$ patients. First, the aetiology of the evolution of anti-NMDA receptor antibodies in patients with preceding herpesviridae encephalitis is still unknown [9]. Although it has been hypothesized that a release of antigens by viral neuronal cell lysis triggers an immune response that is misdirected against a structurally similar epitope present in the NMDA receptor [9], there might be other or additional, so far unknown factors required for the initiation of CNS autoimmunity that are lacking or altered in patients with intrathecal bleeding. Secondly, immune reactivity with detectable levels of autoantibodies could start after the observation period of our patients (in our cohort only 10 out of 54 patients had follow-up sample later than 6 weeks).

There are some limitations of the study, e.g. the small number of patients. One could argue that autoantibodies against neuronal surface proteins might occur at a low frequency, and, therefore, were not detected. Although a higher patient number would strengthen the (negative) results, one has still to consider a false positive rate of the immunofluorescence test of up to $1 \%$ (as determined in healthy individuals) $[10,11]$. Furthermore, as only a small proportion of the entire $\mathrm{SAH}$ and $\mathrm{ICH}$ cohort was eligible for determination of neuronal surface antibodies depending on availability of CSF and serum samples, it cannot be excluded that a selection bias has been introduced. Even though patients requiring ventricular drainage usually present with a more severe disease course, i.e. show more extensive brain damage, that possibly predisposes to secondary immune response formation, these patients typically show more intrathecal blood. It is unclear whether the presence of intrathecal blood might hamper the local establishment of a specific immune reactivity due to its potential ability of blocking epitopes.

Finally, antibodies against neuronal surface proteins cover only a small part of possible antigens against an immune response can be directed. Therefore, screening for antibodies against neuropil as well as determination of antibodies against intracellular epitopes has to be done in a further study.

\section{Conclusions}

Immunoreactivity against common neuronal surface proteins was not observed within the early disease course of spontaneous SAH and $\mathrm{ICH}$.

\section{Abbreviations}

AMPA: a-amino-3-hydroxy-5-methyl-4-isoxazolepropionic acid; CASPR2: contactin-associated protein 2; CNS: central nervous system; CSF: cerebrospinal fluid; $\mathrm{GABA}_{\mathrm{B}}$ : $\mathrm{Y}$-aminobutyric acid type $\mathrm{B} ; \mathrm{ICH}$ : intracerebral haemorrhage; LGI1: leucine-rich glioma inactivated 1; NMDA: N-methyl-Daspartate; SAH: subarachnoid haemorrhage; VGKC: voltage-gated potassium channel 


\section{Funding}

This study has received funding from the Austrian Science Fund (FWF) under project number KLI 375 .

\section{Availability of data and materials}

All relevant data supporting the conclusions of this study are displayed within this manuscript.

\section{Authors' contributions}

$\mathrm{HH}$ has participated in the conception and design of the study, acquisition and statistical analysis of the data, and in drafting the manuscript. RH has participated in reviewing the manuscript for intellectual content. MK has participated in reviewing the manuscript for intellectual content. BP has participated in reviewing the manuscript for intellectual content. AS has participated in reviewing the manuscript for intellectual content. ES has participated in the conception and design of the study, and in reviewing the manuscript for intellectual content. RB has participated in the conception and design of the study, and in reviewing the manuscript for intellectual content. All authors read and approved the final manuscript.

\section{Ethics approval and consent to participate}

The study was approved by the ethics committee of Medical University of Innsbruck (AN4091 292/4.6 (3328a) and AN4088 292/4.3 (3331a)). Written informed consent was obtained from all patients.

\section{Consent to publication}

Not applicable.

\section{Competing interests}

$H$. Hegen declares to have no competing interests.

R. Helbok declares to have no competing interests.

M. Kofler declares to have no competing interests.

B. Pfausler declares to have no competing interests.

A. Schiefecker declares to have no competing interests.

E. Schmutzhard declares to have no competing interests.

R. Beer declares to have no competing interests.

\section{Publisher's Note}

Springer Nature remains neutral with regard to jurisdictional claims in published maps and institutional affiliations.

Received: 11 August 2017 Accepted: 25 June 2018

Published online: 28 June 2018

\section{References}

1. Mracsko E, Veltkamp R. Neuroinflammation after intracerebral hemorrhage. Front Cell Neurosci. 2014;8:388.

2. Macdonald RL. Delayed neurological deterioration after subarachnoid haemorrhage. Nat Publ Group. 2014;10(1):44-58.

3. Armangue T, Leypoldt F, Málaga I, Raspall-Chaure M, Marti I, Nichter C, et al. Herpes simplex virus encephalitis is a trigger of brain autoimmunity. Ann Neurol. 2014;75(2):317-23.

4. Leypoldt F, Titulaer MJ, Aguilar E, Walther J, Bönstrup M, Havemeister S, et al. Herpes simplex virus-1 encephalitis can trigger anti-NMDA receptor encephalitis: case report. Neurology. 2013;81(18):1637-9.

5. Hacohen Y, Deiva K, Pettingill P, Waters P, Siddiqui A, Chretien P, et al. $\mathrm{N}$-methyl-D-aspartate receptor antibodies in post-herpes simplex virus encephalitis neurological relapse. Mov Disord. 2014;29(1):90-6.

6. Mohammad SS, Sinclair K, Pillai S, Merheb V, Aumann TD, Gill D, et al. Herpes simplex encephalitis relapse with chorea is associated with autoantibodies to N-methyl-D-aspartate receptor or dopamine-2 receptor. Mov Disord. 2014;29(1):117-22.

7. Armangue T, Titulaer MJ, Málaga I, Bataller L, Gabilondo I, Graus F, et al. Pediatric anti-N-methyl-D-aspartate receptor encephalitis-clinical analysis and novel findings in a series of 20 patients. J Pediatr. 2013;162(4):850-2

8. Linnoila JJ, Binnicker MJ, Majed M, Klein CJ, McKeon A. CSF herpes virus and autoantibody profiles in the evaluation of encephalitis. Neurol Neuroimmunol Neuroinflamm. 2016;3(4):e245.

9. Höftberger R, Armangue T, Leypoldt F, Graus F, Dalmau J. Clinica neuropathology practice guide 4-2013: post-herpes simplex encephalitis:
$\mathrm{N}$-methyl-Daspartate receptor antibodies are part of the problem. Clin Neuropathol. 2013;32(4):251-4.

10. Dahm L, Ott C, Steiner J, Stepniak B, Teegen B, Saschenbrecker S, et al. Seroprevalence of autoantibodies against brain antigens in health and disease. Ann Neurol. 2014;76(1):82-94.

11. Lang K, Prüss H. Frequencies of neuronal autoantibodies in healthy controls: estimation of disease specificity. Neurol Neuroimmunol Neuroinflamm. 2017:4(5):e386.

\section{Ready to submit your research? Choose BMC and benefit from:}

- fast, convenient online submission

- thorough peer review by experienced researchers in your field

- rapid publication on acceptance

- support for research data, including large and complex data types

- gold Open Access which fosters wider collaboration and increased citations

- maximum visibility for your research: over $100 \mathrm{M}$ website views per year

At BMC, research is always in progress.

Learn more biomedcentral.com/submissions 